\title{
The Young Generations' Conceptualisation of Cultural Tourism: Colonial Heritage Attractions in South Korea
}

\author{
This study investigates how the younger generation conceptualise cultural \\ tourism attractions associated with modern history in contemporary South Korea. \\ Particular attention in this study is given to heritage attractions built in the \\ Japanese colonising past. By analysing data obtained through a Multiple \\ Sorting Procedure, this study identifies the underlying facets of heritage \\ attractions the younger generation consider to be important when appreciating the \\ heritage attractions. This study examines the socio-psychological properties and \\ meanings that the heritage attractions communicate with respect to young \\ Koreans' sense of national identity. This study found that a range of constructs \\ emerged in understanding heritage attractions. Social and political meanings \\ embedded in the heritage attractions become a key determinant in appreciating \\ heritage attractions with respect to a sense of national identity. These findings \\ from South Korea suggest invaluable messages that can inform our understanding \\ of, and planning regenerating negative-natured heritage attractions for tourism in \\ contemporary society.
}

Keywords: the younger generation, heritage attractions, Japanese colonial rule, national identity, a Multiple Sorting Procedure

\section{Introduction}

The link between cultural heritage and tourism is of growing significance. Cultural heritage attractions have become one of the most important tourism resources that can attract tourists to specific tourism destinations and play an important role in leisure activities (Henderson, 2001). But the relationship between heritage and cultural leisure has implications beyond the economic impact of the tourism industry. Heritage in a tourism context is significantly linked to nationalism (Rakić, 2008). As a vehicle for national history and national identity, the relationship between cultural heritage and a sense of identity usually focuses on the positive aspects of cultural heritage, that is, those elements which support the creation of uniform identity (Bhandari, 2011). 
However, some cultural heritage attractions find themselves situated in a contested arena in society due to the deliberate infliction of atrocities associated with the places in the past (Tunbridge \& Ashworth, 1996; Logan \& Reeves, 2009). Moreover, cultural heritage can be a source of dissonance, contested memory, identity and social and cultural value in society (Tunbridge \& Ashworth, 1996; Macdonald, 2006a, 2006b; Dolff-Bonekämper, 2010). As a consequence of this, the 'virtuous' qualities of cultural heritage for tourism may be in conflict. In South Korean society, the Japanese colonial rule (1910-1945) bequeathed a number of material legacies of Japanese imperial dominance and colonial power. While many vestiges of colonisation have been removed since the liberation from Japan in 1945, some historic places in the colonial-era are officially preserved as registered modern cultural heritage or tourist attractions. The interpretation of cultural heritage attractions associated with the colonising past has frequently been linked to the Korean's nationalism (Chung, 2003; Jin, 2008; Kim, 2009; Park, 2012) and the attractions have sometimes been shown as architectural legacies of colonialism that still affects Korean identity (Park, 2012). It is exactly seventy years since the end of the Japanese rule of Korea. Although some generations with first-hand memory of the colonising past remain alive, most generations today no longer have a living connection with the colonising past; it has moved from personal memory to collective memory (Assman, 2011). The younger generation South Koreans, especially, have grown up in a society holding less nationalistic ideas based on a colonial past. They are less likely to experience the past political and ethnic conflict between Korean and Japanese nationality than any previous generation. Time changes how we experience the past and the stories we tell. The greater the psychological distance to the cultural heritage, the more cultural heritage is general and abstract (Massara \& Severino, 2013). Even the massacre site during the 
Second World War (e.g., Oradour-Sur-Glane in France) illustrates that a historic site that provides a powerful affective and emotional heritage experience, slowly mutates into a site providing a cognitive experience in a present day (Uzzell, 1989). If we accept that meanings of cultural heritage are subject to change, it could be assumed that not all heritage attractions will be perceived to be crucial to a sense of national identity. Many of them would be mundanely experienced by the younger generation and the regeneration of the heritage based on nationalism will not be supported. Moreover, as Graham (2002, p. 1004) points out, 'If heritage is the contemporary use of the past, and if its meanings are defined in the present, then we create the heritage that we require and manage it for a range of purposes defined by the needs and demands of our present societies'. For sustainable cultural heritage attractions, cultural heritage attractions need to be revitalised by addressing people's present experiences and interests. Although there is some research literature which critically discusses the significance of colonial heritage as a touristic, commercial, cultural or educational asset in contemporary society (e.g., Henderson, 2001; Jenning, 2003; Peleggi, 2005; Ravi, 2008; Chang \& Teo, 2009; Wong, 2013; Cheer \& Reeves, 2015), fundamental questions about how these attractions are conceptualised by new generations has been little studied. The association of cultural heritage with national identity has been the subject of study for a number of heritage and tourism researchers in recent times (e.g., Palmer, 1999, 2005; Rakić, 2008; Bhandari, 2011, etc.). However, a particular shortcoming of some of this research is that the limited range of methodologies employed in current heritage tourism (i.e., largely questionnaires) has resulted in vague and poorly operationalised studies that do not always furnish the kind of insights that this research question requires. Accordingly, this study addresses the necessity for an empirically-driven study that investigates how the younger generation who have grown up in present-day 
South Korean society conceptualise colonial heritage attractions, which employs a methodology that accesses the conceptualisation process in which the young generations engage. Therefore, the research sought to answer three critical questions. First, this study explores what underlies the younger generation's appreciation of colonial heritage attractions (Research question 1). Second, this study examines what kind of properties and meaning colonial heritage attractions communicate with respect to a sense of national identity (Research question 2). Third, this study explores how colonial heritage attractions can be classified with respect to a sense of national identity in present-day South Korean society (Research question 3). These questions are important in a country like South Korea where its colonising history is critical in forming citizens' sense of national identity. These questions are also pertinent when it comes to issues such as the management of heritage attractions in a postcolonial society. This understanding should provide heritage practitioners with critical information on the use of colonial-era heritage for tourism today. Furthermore, the findings of this study will suggest effective communication strategies with contemporary visitors who are seeking to experience colonial-era cultural heritage.

\section{Literature Review}

\section{Heritage tourism and national identity}

In contemporary societies, association of cultural heritage with national identity and nationalism has long constituted an important domain of research in heritage studies. Few would doubt the powerful role of cultural heritage in fostering a sense of national identity. Heritage and nationalism can sit together quite comfortably in the context of tourism (Rakić, 2008). The experience of nationally symbolic places, such as buildings, landscapes, and monuments that strengthen a sense of collective belonging, encourages individuals to experience identity and make them change and restructure 
their identity (Palmer, 1999, 2005). The relationship between heritage tourism and the construction of identity has empirically been evidenced in much of the recent tourism and heritage literature under their own research interests, such as Palmer's $(1999,2005)$ study of national identity experienced by the English, as well as Bhandari’s (2011) study of the role of dominant heritage in the creation of Scottish identity. Palmer (1999) argues that as language, ethnic, and religion is central to culture, heritage becomes a key element promoting national identity. Therefore, heritage tourism becomes an important means of constructing and maintaining national identity since the historic symbol of the nation's identity, a main resource of heritage tourism, can define nation-ness and attract tourists to the nation and the place. This correlation echoes Palmer's later study (2005) identifying the processes which enable people to experience English national identity (i.e. Englishness) at nationally significant heritage attractions (Battle Abbey, Hever Castle, and Chartwell). She suggests that heritage attractions where Englishness is symbolised make visitors feel kinship ties and bind them to the nation. Bhandari (2011), like Palmer (1999, 2005), focuses much attention on the way in which heritage tourism is explicit in the construction of homogenous identity in a Scottish context. Bhandari (2011) empirically demonstrates that recreating heritage tourism products, especially the dominant 'Highland' heritage in the region can serve as a powerful medium to booster a nationalistic message and meaning. Additionally, not only does the consumption of heritage products encourage visitors and locals across the region to become 'Scots', but it also makes them see the region as typical of Scotland. Another example of this view is provided by Rakić's (2008) examination of the role of cultural heritage and tourism in the construction and consumption of 'Greekness'. He argues that despite its status as a World Heritage site, visitors to the Athenian Acropolis 
are highly likely to perceive the historic site as the symbol of Greekness rather than the symbol of world heritage that represents universality.

Given this positive role of heritage tourism, it has long been the trend to appreciate historic places as 'a cultural legacy which is both good and necessary, something that should be cherished and preserved, celebrated and promoted for its ability to represent a wide range of social and cultural identities' (Anico, 2009, p.63). However, arguments are being increasingly voiced that not all cultural heritage reflects the positive side of history that is to be cherished and celebrated. Some historic places may be perceived as 'commemorating conflict, trauma and disaster' (Rico, 2008, p.344). Given that cultural heritage serves as a physical proof of identity, this type of cultural heritage attraction becomes problematic and introduces a number of complex and important challenges in terms of the traditional role of cultural heritage in identity construction. There is terminological inflation along with a growing interest in this negatively constructed heritage, such as dissonant heritage (Tunbridge \& Ashworth, 1996; Ashworth, 2002; Graham, 2002), negative heritage (Meskell, 2002), sites of discord value (Dolff-Bonekämper, 2008, 2010), undesirable heritage (Macdonald, 2006a), ambivalent heritage (Chadha, 2006), difficult heritage (Logan \& Reeve, 2009), contested heritage (Tunbridge, Jones \& Shaw, 1996; Shaw \& Jones, 1997), dark heritage (Biran et al, 2011), and hot interpretation (Uzzell, 1989, 1998; Uzzell \& Ballantyne, 1998). This category of cultural heritage (under whatever heading) serves a touristic function that provides people with meanings and significance of heritage which traditionally would not have necessarily been seen as an appropriate destination for a tourism experience. Of course, it was the First World War when the war dead were buried where they fell, that led to the rising numbers of grieving relatives who wanted to visit the last resting place of their spouses, parents and children but their 
journey was an act of remembrance and would not have been seen to be a tourism with all its associations of enjoyment and relaxation. By extension, the meanings and significances of this form of cultural heritage is now seen to play a crucial part in community development through community reconciliation and nation building, or defusing religious or ethnic conflicts (Uzzell \& Ballantyne, 1998; Langley, 2011). These concepts sometimes overlap, so there is no clear-cut distinction among these concepts. However, the common factor from these concepts is that they attached great importance to meaning associated with cultural heritage and a sense of place driven from people's experiences.

The dilemmas of negative-natured heritage and its relationship to the construction of identity have been actively debated. For instance, Chung (2003, p.235) argues that negative-natured historic buildings remain 'a monumental object of the maker and the original owner'. Hence, no matter how the purpose of negative-natured historic buildings has changed, these buildings continue to be associated with painful and shameful periods and remain as historic symbols. Meskell (2002) points out that negative cultural heritage in a social context can be appropriated for use as a memorial of the past and used for educational purposes today (e.g. Auschwitz, District Six (Cape Town)). Otherwise, it could be removed as a form of history that is designated as unworthy and undesirable and cannot be culturally rehabilitated until now (ibid). Examples of this are Nazi monuments and Communist monuments in Eastern European nations.

A similar problem also arises from the use of colonial-era heritage for tourism. In recent decades, there has been a considerable body of literature devoting attention to the use and renovation of a legacy of the colonial past for tourism, especially for historic hotels (e.g. Henderson, 2001; Jenning, 2003; Peleggi, 2005; Ravi, 2008; Chang 
\& Teo, 2009; Cheer \& Reeves, 2015). Palmer (1994, p. 808) asserts that 'colonialism was concerned with power, domination, and control, and with the superiority of one group over another through the perpetuation of inequality'. In the light of this consideration, she suggests that heritage tourism based on the colonial past only serves to perpetuate colonialism in a society after its liberation. By focusing on the redevelopment of a colonial-era hotel in Fiji, Cheer and Reeves (2015) convincingly argue that renovating colonial-era heritage for tourism becomes problematic locally because of the historic meanings that the heritage possesses. That is to say, historic places associated with the history of negative events have been viewed as being representative of past conflicts due to both the message and the sense of place people perceived (Tunbridge \& Ashworth, 1996; Dolff-Bonekämper, 2010).

While these studies highlight problems arising from the use of colonial heritage in a postcolonial context, some studies focus much attention on its positive roles, especially for the tourism industry (e.g. Henderson, 2001; Peleggi, 2005; Wong, 2013). The term 'heritage' has frequently used as one of the marketing strategies in attracting tourists to a variety of places (Palmer, 1999). From a tourism marketing perspective, Peleggi (2005) examines whether monumentalised colonial-era hotels in postcolonial society in South-East Asia are regarded as commodified heritage sites or 'mnemonic places'. He defines historic hotels as mnemonic sites that make the colonial past available as 'a stage set for consumption practices' (p.264). Wong (2013) also points out that both tangible and intangible heritage associated with the colonial history of Macau plays a key role in attracting international tourists including Chinese tourists, and promotes Macau as a heritage tourism destination. This understanding echoes Henderson's (2001) study identifying the interconnectedness of colonial heritage, national identity, and tourism in Hong Kong, a tourist destination with a colonial 
history. As Hong Kong comprises a distinctive identity that combines its Chinese history and a British colonial past, potential conflicts of its meanings still exist in the context of decolonisation. However, although cultural heritage attractions associated with its Chinese and British colonial past serve as a medium for the promotion of cultural identity, it also makes Hong Kong a competitive tourism destination in a tourism market where homogenisation is a dominant force. Moreover, the colonial heritage attractions in Hong Kong are part of an ever-evolving national identity which is being constructed by its inhabitants after the replacement of British rule by Chinese.

\section{Heritage as a social process}

UNESCO (2013) describes cultural heritage as 'our legacy from the past, what we live with today and what we pass on to future generations'. Traditionally and conventionally, the materialist approach to cultural heritage has focused mainly on objectified or materialised heritage (Smith, 2006, 2007). However, recent heritage scholars have introduced a modern concept of heritage by shifting emphasis from the material to the intangible heritage and seeing a complex interweave between materiality and subjectivity (e.g. Graham, 2002; Garden; 2006; Dolff-Bonekämper, 2010). Cultural heritage is more than a simple legacy from the past, going beyond the materiality of heritage (Smith, 2006; Moles, 2009).

A key to recent arguments is the complexity of socially constructed meanings of cultural heritage (Dolff-Bonekämper, 2010). By moving away from treating cultural heritage as a fixed tangible past material that can be isolated from the present societal context, attention has been given to the questions of how cultural heritage is interpreted in the present societal context and how it is situated in a social process. The premise of this understanding lies in an attempt to understand cultural heritage as socio-cultural 
construction, constructed at specific social, historical and living contexts, rather than a naturally occurring phenomenon or universal (Kaplan, 2009; Prats, 2009). Cultural heritage becomes a contemporary product that is always socially revised, manipulated and contested under the pressure of contemporary demands, interests, or moralities (Witcomb, 2009). Accordingly, the heritage of atrocities would also induce controversies in a present-day political and cultural context because it induces many different layers of meanings and values associated with a specific space and time (e.g. Tunbridge \& Ashworth, 1996; Ashworth, 1998; Dolff-Bonekämper, 2008).

This argument goes further by proposing that cultural heritage could be interpreted differently, not only between cultural contexts, but also within any specific culture at any one time (Graham, 2002). By emphasising cultural heritage grounded in a social frame, cultural heritage is appreciated as a contemporary social product, which is a representation of the past in the present day (Lowenthal, 1998). Since meanings of cultural heritage are constantly redefined and reshaped on the basis of present interests and purposes, the meaning of cultural heritage differs over time and for different groups of people (Graham, 2002; Uzzell, 2009). Urry (2000, p.115) states that 'what we take to be the past is necessarily reconstructed in the present, each moment of the past is reconstructed in the present'. Taking this view, Crouch and Parker (2003, p.398) also conceptualise cultural heritage as 'the crystallisation of recurrent, dominant and new representation of past time, practice and place'. Tunbridge and Ashworth (1996, p.6) add that 'the present selects an inheritance from an imagined past for current use and decides what should be passed on to an imagined future'. Seen from this point of view, the negative-natured historic places come to act as authentic memorials to painful experiences of the past and thus an explanation of the present (Harrison et al., 2008). All these recent understandings of cultural heritage imply that although cultural 
heritage, including historic architecture, monuments and memorials, is durable, it does not remain static or frozen in time (Smith, 2006; Uzzell, 2015). In other words, the original version of the past is replaced in present circumstances.

Another key perspective highlighted in recent heritage study is that people lie at the heart of this socio-cultural process that is consistently evolving. They are actively and subjectively aware of the past and meanings of cultural heritage, rather than merely passive receivers of it (Harvey, 2001; Byrne, 2003; Macdonald, 2006a; Smith, 2006). Cultural heritage has consistently been reconstructed and transformed with reference to people's present experiences and interests (Harvey, 2001). As the significance or meaning of cultural heritage is simultaneously inherited and transformed drawing on individuals' own living experience (Byrne, 2003; Smith, 2006), identity may not be simply something produced by cultural heritage, but is something actively and continually transformed by people and communities' reinterpretation and reassessment of their past (Harvey, 2001; Smith, 2007).

\section{Method}

\section{Multiple Sorting Procedure}

Given the critique above, it is apparent that the meanings of negative-natured heritage attractions are subject to not only what is interpreted, but also how it is interpreted and by whom. In order to explore this and derive some insights and understanding of these means, it was decided that a multiple sorting procedure would be the most appropriate methodology. Our approach to this is derived from Canter, Brown, and Groat's (1985, p. 79) notion that 'an understanding of the categories people use and how they assign concepts to those categories is one of the central clues to the understanding of human behaviour'. Multiple Sorting Procedure is 'a technique for examining how participants 
place constructs into categories and how they then label the distinctions between the categories' in any given context' (Barnett, 2004, p. 289). This technique has been used not only in psychological research in general which emphasises the importance of categorisation processes (Barnett, 2004), but also environmental psychology in studies which explore, for example, the meaning of architecture (Groat, 1982), the education and development of architectural concepts (Wilson \& Canter, 1990), the aesthetic judgement of architectural design (Hubbard, 1994), the interpretation of built environment (Hubbard, 1996a, 1996b), socialisation and architectural preference (Wilson, 1996), landscape perception (Scott \& Canter, 1997), and social attribution and interior style (Wilson \& Mackenzie, 2000). One reason for this is that this technique is able to overcome the shortcomings of questionnaires and interviews in that it does not overly restrict or frame participants' responses, but rather enables the exploration of participants' conceptual systems (Groat, 1982; Scott \& Canter, 1997). In contrast with a researcher-imposed approach, the Multiple Sorting Procedure allows participants to freely categorise provided materials to be sorted (e.g. photographs, card with words, drawings) using their own idea, constructs and conceptual systems. By sorting materials that characterise the area of interest, participants are encouraged to articulate what they give priority in constructing a certain issue and thus reveal its meaning. The Multiple Sorting Procedure produces structured data sets which can be analysed by sophisticated techniques, such as Partial Order Scalogram Analysis (POSA), Smallest Space Analysis (SSA) and Multidimensional Scalogram Analysis (MSA). Therefore, this technique explores participants' construct systems in a structured and systematic manner (Barnett, 2004). For the above reasons, the Multiple Sorting Procedure was adopted for understanding how individuals conceptualise heritage attractions and what constructs and categories they use to interpret the heritage attractions. 


\section{Participants}

Using non-probability sampling techniques, twenty young adult South Koreans were recruited in Seoul and Seoul metropolitan area in South Korea. Participants were approached by emails or telephone calls to local educational institutions, and religious activity centres and voluntary organisations in Seoul and Seoul metropolitan area. Additionally, the researcher asked potential participants to recommend others they may know who also met the criteria (e.g. age, residence, and nationality). The younger generation were defined as young adult South Koreans above eighteen years and under thirty years old. The samples from the younger generation were selected on the basis that they had grown up when South Korean society began to import Japanese popular culture in the 1990s (e.g. anime, movies, drama, music). A sample size of fifteen to twenty participants is sufficient to produce a stable structure using a Multiple Sorting Procedure (Wilson \& Canter, 1990; Wilson \& Mackenzie, 2000).

\section{Photographic Card-Sorting Task}

A card-sorting task used a set of colour photographs of twenty-four historic places in the centre of Seoul, constructed in the period of colonial rule (1911-1945), comprising four of each of the following six architecture types: government-related architecture, educational buildings, commercial business buildings, public cultural buildings, residential buildings, and religious facilities (Table 1). The researcher was able to determine the salience of the colonial heritage attractions from data collected in another study which was undertaken as part of this same research project.

$<$ Table 1 A set of colonial heritage attractions for a card-sorting task $>$ 
This study adopted two methods to improve the validity of photograph techniques. First, a sample of the participants was asked whether it was difficult to recognise colonial heritage attractions that had been taken. By discarding and changing unrecognised photographs of colonial heritage attractions, photographs which best clearly represented the subject of heritage attractions were selected. Second, identification of colonial heritage attractions in the photographs was enhanced by attaching labels to the front of photographs indicating the name of the heritage sites so there was no ambiguity. Additionally, each photograph was numbered from one to twenty-four in order to facilitate recording the information of each sort.

\section{Sorting Procedure}

The sorting procedure in this study was developed in line with the procedure suggested by Canter et al. (1985) and Barnett (2004). The card-sorting task comprised both a free sort and a structured sort. By analysing criteria freely used by participants, free sorting tasks aimed to explore the underlying facets of colonial heritage attractions they consider to be important when appreciating colonial heritage attractions. At the beginning of the task, the researcher introduced participants to the nature of the study and gave them twenty-four photographs representing heritage attractions associated with the Japanese colonial past. Canter et al. (1985) and Barnett (2004) agree that twenty-four photographs are a sufficient number for a sorting task. The participants were given five minutes to familiarise themselves with the attractions on the photographs. Thereafter, the participants were encouraged to sort the photographs into groups using criteria that they felt important in making distinctions between the heritage attractions. No restriction was made on the number of groups (i.e. categories) or the number of photographs within each group (i.e. distribution) to identify various aspects 
of their idea of colonial heritage attractions. This sorting process was continued until their selection was exhausted.

The structured sorting tasks aimed to explore socio-psychological properties and meaning that colonial heritage attractions communicate with respect to a sense of national identity and to classify the attractions with respect to a sense of national identity. Four sorting criteria were defined: 'significance to national identity', 'potential to threaten national identity', 'typical colonial legacies', and 'attachment to the heritage attractions'. Participants were asked to classify photographs of colonial heritage attractions according to the degree of their assessment of each sorting criterion and to categorise the photographs into three different groups, such as 1) very, 2) quite, and 3) not at all. All participants were interviewed individually to carry out the cardsorting task.

\section{Analytical Procedure}

Using content analysis, the large volume of data obtained through free sorting tasks was reduced into more manageable groups. This procedure involved categorising the sorts on the basis of conceptual similarity and extracting key statements from the sorts to capture the original meanings. In order to achieve a high level of reliability in coding structure, the content analysis was undertaken by two independent raters. The intercoder reliability for each of the category description (i.e. the Inter-Rater Kappa Coefficients for the Content Analysis) was 0.924, which indicates that the coding was highly reliable.

Secondly, Guttman's Partial Order Scalogram Analysis (POSA) was used for the data obtained through structured sorting tasks. This specific form of Multi-

Dimensional Scaling procedures (Guttman \& Greenbaum, 1998) identifies how each of 
the variables (i.e. structured sorts) relate to one another, and how each combination of the variables related to the items themselves, consequently revealing underlying structures and relationships implicit in individuals' multi-criteria decisions (Sixsmith, 1986; Wilson, 1995; Wilson \& Hammond, 2000). The results of the analysis were presented in a graphical form that allows visual interpretation of the complex relationships between four structure sorts as a set of points in two-dimensional spaces. The spatial distance between the points in multidimensional spaces indicates the conceptual similarity between profiles (Coxon, 1982). POSA produces an overall plot diagram representing the similarities and differences among items as well as a series of item diagrams for each of the variables (Wilson \& Canter, 1993). The individual item diagrams provided by POSA help in determining why the profiles differ and how these variables (i.e. features) contribute to the overall POSA diagram (Canter, 2004). Plots in the individual item diagrams can be divided into regions according to each different category of a construct. Six major ways to partition plots is widely accepted in POSA: X, Y, J, L, P, and Q-axes (Figure 1). The Hebrew University Data Analysis Programme (HUDAP) was used for the analysis in this study.

$<$ Figure 1 Types of Partitioning in POSA $>$

(Source: Taylor, 2002; Tzfati et al., 2011)

\section{Results}

\section{Underlying Facets in Appreciating Colonial Heritage Attractions}

Content analysis was carried out in order to explore what underlies the younger generation's appreciation of colonial heritage attractions (Research question 1). Fiftysix different sorts carried out by participants were grouped into fifteen distinct 
categories of constructs that emerged from the criteria, which indicate the constructs and categories participants use to appreciate the attractions. Afterwards, the fifteen constructs were aggregated into four broad construct categories: socio-historic, architectural properties, community life and personal affective (Table 2). The results show that architectural properties of heritage attractions are of great concern to the younger generation when appreciating colonial heritage attractions (41.1\%, 23 sorts), which implies they relied heavily on physical cues in viewing colonial heritage attractions. These include architectural style, visual image from the external appearance, physical structure, scale and materials, and location of the attractions. Following the constructs based on the architectural properties, a large percentage of constructs identified by the younger generation were concerned with socio-historic factors of colonial heritage $(32.1 \%, 18$ sorts $)$. What these constructs have in common is colonial heritage attractions were evaluated based on the political and social meanings embodied in the heritage. These include the socio-historic values of the heritage, its symbolic roles in the colonising society, symbolic meanings associated with colonial heritage in Korean history, and collective sentiment based on the colonising past (e.g. sadness, antagonism, etc.). Colonial heritage attractions were also appreciated with respect to their functions in the community today $(16.1 \%, 9$ sorts $)$ that are significant to qualities of their everyday lives. There were three dominant concerns with respect to current community life: the current functions of the places in a community, the usefulness of the places today, and the functions of the places. The participants also appreciated colonial heritage attractions based on their personal emotions towards the attractions $(10.7 \%, 6$ sorts $)$. The attractions were appreciated according to levels of personal familiarity, personal preference and interests. 
$<$ Table 2 Frequency of the main themes used in free sort $>$

\section{Socio-psychological Properties of Colonial Heritage Attractions}

A Partial Order Scalogram Analysis (POSA) of the twenty-four colonial heritage attractions across the four structure sorts was performed in order to explore sociopsychological properties that colonial heritage attractions communicate with respect to a sense of national identity (Research question 2). The results were represented geometrically as points in the two dimensional spaces, which is the key part of the POSA. Figure 2 presents an overall plot representing the similarities and differences among the colonial heritage attractions. A series of plots for each of the structure sort (i.e. 'typical colonial legacies', 'attachment to the heritage attractions', 'significance to national identity', and 'potential to threaten national identity') are shown in Figures 3. The coefficient of corrected representation (CORREP) is 1.00; indicating the plot correctly represented $100 \%$ of the profile pairs (i.e. a perfect fit) and all profiles were partitioned into a space without exception. The colonial heritage attractions employed in the analysis are scattered across each plot. Twelve unique profiles were derived from the set of twenty-four colonial heritage attractions, which indicates some heritage attractions shared an identical profile with other attractions. The heritage attractions that have often been conceptualised in the same way were closely positioned. Thus, the greater the similarity between the heritage attractions according to the profile, the closer they are together in the space and vice versa. There are clear differences between government-related heritage attractions (e.g. the old building of Seoul City Hall), located in the bottom left hand side, and residential buildings, mainly in the upper right-hand side of the space. 
$<$ Figure 2 Main POSA plot for colonial heritage attractions $>$

To measure the differences among the colonial heritage attractions, each of the four plots was divided in a way to ensure the regions comprise the same score for profiles on those items. Each variable's coefficient of monotonicity was above 0.8 , which indicates the division is accurate.

First, the item measuring 'potential to threaten national identity', which is whether colonial heritage attractions have the potential to threaten Korean identity, is partitioned along the $\mathrm{X}$-axis with coefficients of monotonicity of 1.00 in the two dimensional space. This shows all government-related historic places and public architectural attractions are appreciated as a prominent structure that has the potential to threaten Korean identity (profile 2). The majority of commercial, business and educational architectural heritage that have played socially important roles in Korean society, as well as religious facilities built under colonial rule, are also appreciated as the same type of colonial heritage attractions. All Japanese-styled residential houses, which are physically significant but politically irrelevant, and the majority of cultural facilities, which are politically irrelevant, are appreciated as historic structures that have not the potential to threaten Korean identity (profile 3 ). This implies the political or social relevance of colonial heritage would become a key determinant in appreciation of colonial heritage attractions that threaten the younger generation's sense of Korean identity, rather than physical features of colonial heritage attractions.

$<$ Figure 3 (a) Item plot for 'potential to threaten Korean identity'> 
Second, the item measuring 'attachment to the heritage attractions', which is whether participants are attached to colonial heritage attractions, is partitioned along the Y-axis with a coefficient of monotonicity of 1.00 . The findings demonstrate that the younger generation have a sense of attachment towards the majority of heritage attractions with which they have frequent contact in their social life. However, all Japanese-styled houses and religious facilities and the majority of educational architecture were conceived as the least attached heritage. This implies the younger generation's sense of attachment to colonial heritage attractions relies heavily on the attractions' socio-cultural role and position in society.

$<$ Figure 3 (b) Item plot for 'attachment to the heritage attractions' $>$

Third, the item measuring 'typical colonial legacies', which is whether heritage attractions are viewed as typical Japanese colonial legacies, is partitioned along the Qaxes with coefficients of monotonicity of 0.99 . This configuration indicates the majority of colonial heritage attractions are viewed as typical Japanese colonial legacies. Especially, the old buildings of Seodaemun Prison and Seoul City Hall, which are symbolic colonial government-related attractions representing colonial dominance and political oppression under Japanese rule, appear as the most typical Japanese colonial legacies. On the other hand, a Japanese religious facility (e.g. temple 3) and the old Dongdaemun Stadium, which are less politically relevant, do not appear as Japanese colonial legacies. This result provides evidence that colonial legacies are not determined through visually displayed distinctive physical features of colonial heritage. Rather, it relies heavily on invisible messages and meanings embodied in the heritage attractions. 
$<$ Figure 3 (c) Item plot for 'typical Japanese colonial legacies'>

Lastly, the results for 'significance to national identity', which measure the significance of colonial heritage attractions to a sense of Korean identity, shows parallel patterns to those for the item measuring typical colonial legacies. This configuration indicates the old buildings of Seoul City Hall and Seodaemun Prison in the lower lefthand side in the Q-partition, are the most significant to a sense of Korean identity. In contrast, Japanese religious facilities and Japanese-styled residential houses in the top right-hand side are not significant to a sense of Korean identity.

$<$ Figure 3 (d) Item plot for 'significance to Korean identity'>

The partitions explored by four variable items (From Figures 3 (a) to 3 (d)) are superimposed in order to understand the socio-psychological properties of colonial heritage attractions (Figure 4). The solid lines in the superimposed plot represent the partitions into regions according to the basic items (i.e. $\mathrm{X}$ and $\mathrm{Y}$ axes), which are 'potential to threaten national identity' and 'attachment to the heritage attractions'. These regions are divided by the other two items working as a combination of the basic items (i.e. Q axis), ‘typical colonial legacies' and 'significance to national identity', which are illustrated by broken lines.

The plot shows the major division of colonial heritage attractions that emerges to distinguish between two extremes groups of the attractions in terms of national identity. One extreme group of the heritage attractions in the bottom-left of the plot has a higher degree of all four variable items explored. The heritage attractions in this group include the old buildings of Seoul City Hall and Seodaemun Prison. This 
implies that the government-related heritage attractions are more likely to be appreciated as typical colonial legacies that have the significant potential to challenge a sense of Korean identity. In contrast, the other extreme group of the heritage attractions shown in the upper right-hand side has a lower degree of all four variable items. This group of the attractions includes Japanese-styled residential houses. Although Japanese-styled residential houses and some religious facilities, which visually display distinctive physical features of Japanese heritage, are viewed as typical colonial legacies, they are not linked to a sense of national identity.

The appreciation of educational, commercial business and public cultural heritage attractions are more complicated. They are also important to a sense of Korean identity, although these heritage attractions are less significant, in comparison with the government-related heritage attractions. However, their impact on a sense of Korean identity may not always be negative. Some public and cultural heritage attractions, including theatres (i.e. the Seoul Assembly Hall, the Myungdong Art Hall) and a public stadium (i.e. the old Dongdaemun Stadium), are not perceived as colonial legacies that have the potential to threaten a sense of national identity. However, some public-related attractions that have played an important socio-economic role in both colonial and post-colonial South Korean society (e.g. the old building of Seoul Railway Station and Korean Bank) are viewed as colonial legacies which have a potential to intimidate a sense of Korean identity.

A sense of attachment overlaps with the regions where the group of colonial heritage attractions linked to Korean identity is located. For instance, the old building of Seoul City Hall is simultaneously experienced as a typical colonial legacy that has the significant potential to threaten Korean identity and a heritage attraction to which they are strongly attached. This overlap provides evidence that not only are Japanese 
colonial heritage attractions experienced from the perspective of the national historical context, but they also are simultaneously experienced from other contexts.

$<$ Figure 4 Superimposed four variable items $>$

\section{Classification of Colonial Heritage Attractions}

In order to classify colonial heritage attractions with respect to a sense of national identity (Research question 3), the heritage attractions were discriminated according to features obtained through the partial order structure of each of four variable items. This would give rise to three broad types of colonial heritage attractions in a South Korean context, which are 'symbolic colonial heritage', 'modern historic attractions', and 'historic places in a foreign style' (Figure 5).

Some colonial heritage attractions are viewed in a stereotypical way such that the typical Japanese colonial legacies are seen to intimidate a sense of Korean identity significantly, which can be thought of as 'symbolic colonial heritage' (Region A). Politically remarkable colonial heritage attractions in South Korean society are seen in this light. This type of colonial heritage attractions includes the old buildings of Seoul City Hall and the Seodaemun Prison in this research context.

Socially significant colonial heritage attractions in South Korean society are appreciated as 'modern historic attractions' influencing a sense of Korean identity (Region B). Some government-related heritage attractions, educational, commercial business, and public culture-related attractions are seen in this light. Unlike 'symbolic colonial heritage', the significance of these attractions to a sense of national identity is not always accompanied by threats to national identity. 
The Japanese-styled residential houses and religious facilities differ considerably from the government-related attractions in that these places, which are politically irrelevant but physically significant, are not construed as colonial heritage linked to a sense of national identity. A common feature of these attractions is that the place prominently displays unique physical features that younger generation South Koreans could easily discriminate from their own cultural heritage. Therefore, this type of colonial heritage attractions is thought of as 'historic places in a foreign style' that display unique architectural characteristics (Region C).

$<$ Figure 5 Classification of colonial heritage attractions $>$

\section{Conclusion}

This study explored the ways in which younger generation South Koreans conceptualise colonial-era heritage attractions in contemporary South Korean society. In South Korean society, colonial heritage built in the period of Japanese rule has been implicated as an important contributor to Korean identity. However, the ways in which colonial heritage attractions are actually interpreted by the younger generation in contemporary South Korean society remains underexplored and poorly understood. From a methodological point of view, this study had the advantage that it explores peoples' conceptual systems without framing their response based on the researchers' conceptualizations of the issue and their construct systems; this is a one shortcoming with interviews or questionnaire studies. The Multiple Sorting Procedure employed in this study provided a useful theoretical as well as methodological base from which to explore the underlying dimensions of the younger generation's interpretation, 
understanding and evaluation of Japanese colonial heritage attractions. The graphical form of the information obtained through Partial Order Scalogram Analysis not only enabled the identification of the socio-psychological properties that colonial heritage attractions communicate with respect to a sense of Korean identity, but it also classified colonial heritage attractions in a South Korean context. Key findings in this study identify a number of important issues.

First, younger generation South Koreans appear to see colonial heritage attractions in different ways and their evaluation criteria vary from person to person. Although many constructs are shared, a wide range of constructs are shared in categorising colonial heritage attractions, which reveals that constructs are not simply based on particular architectural properties of the attractions. Some appreciations are tied to physical features of the attractions whilst others are more concerned with the socio-historic meanings embedded in the heritage. These are also often linked to the functions the attractions serve in the community today as well as personal emotions and feelings towards the heritage.

Second, colonial heritage attractions are not automatically imbued with the same meanings in respect of national identity. It was understood that a sense of national identity communicated through colonial heritage attractions does not automatically highlight a sense of potential threat to Korean identity. There is a wide range of heritage attractions, ranging from the colonial heritage attractions not associated with a sense of Korean identity through to the colonial heritage attractions playing a highly significant role in a sense of Korean identity. Colonial heritage attractions that have served politically or socially significant roles in both colonial and post-colonial South Korean society are only seen as colonial legacies that have potential to threaten Korean identity. The evidence presented in this study suggests colonial heritage attractions 
can be classified into three different types of heritage attractions. Thus, it could perhaps be claimed that it would be too simplistic to regard colonial heritage attractions as simply architectural manifestations of threatened national identity.

Third, seen from a national identity perspective, it could be claimed that physical features of colonial heritage attractions do not solely determine younger generation South Koreans' appreciation of the heritage attractions. Rather, political or social meanings embedded in colonial heritage attractions become a key determinant in the communication of national identity. The messages and meanings people perceive make a negative-natured historic place a representative of past conflict (Tunbridge $\&$ Ashworth 1996; Dolff-Bonekämper 2010).

Lastly, younger generation South Koreans employ complex, multi-level viewpoints in conceptualising colonial heritage attractions. They appear to have a sense of attachment to some colonial heritage attractions, regardless of institutional meanings embedded in the attractions. This suggests that a consideration of the multidimensional facets of colonial heritage attractions is necessary in order to understand the significance of colonial heritage attractions.

Since this is a context-specific research, the findings and implications of this research may not be fully transferable across other research contexts. It would be interesting to see whether the heritage in other recent post-colonial societies is understood similarly by the younger generation of those societies, or is their something about Korean culture and heritage that is responsible for the views expressed here. The major implication of this study is that this research has demonstrated empirically that there is a relationship between the younger generation's conceptualisation of the heritage and their sense of national identity. The association of cultural heritage with identity has long constituted an important domain of research in heritage studies. 
Despite its importance, this issue has received little attention and even less empirical evidence of how colonial heritage attractions are understood, particularly in relation to national identity. The Multiple Sorting Procedure affords an insight into the multidimensional meanings and significance of heritage attractions for a sense of national identity that, to the researchers' knowledge and beliefs, has not been achieved in previous tourism studies. We suggest that this study moves beyond the state of the art of many tourism studies that address cultural heritage attractions in terms of sociocultural places where national and cultural identities are produced.

From a practical point of view, these findings from South Korea present invaluable messages that can contribute to revitalising negative-natured heritage attractions for tourism in contemporary society. First of all, the study suggests, for example to heritage and tourism professionals, that understanding people's conceptual system for interpreting colonial heritage could be an important starting point for understanding the significance of colonial heritage for tourism development. Despite being historic attractions representing the colonial past, all colonial-era historic places and attractions would speak not only of cultural imperialism. Although postcolonial society may share a common idea of colonial heritage, the younger generation have somewhat different ideas about colonial heritage. Their understanding of the heritage leads them to approach and use heritage attractions in different ways and to have different expectations towards heritage management. As a consequence of this, it is important to be aware of potential conflicts in the management of historic resources in a tourism context. Tourism and heritage professionals and practitioners need to consider the multiple facets of colonial heritage attractions in contemporary society. It is clearly important to design different strategies for different target groups who may be 
attracted to colonial heritage attractions, according to the different facets that the heritage represents today.

In a same vein, ignoring the new meanings attributed to the younger generations' everyday lives would not only impact negatively on efficient heritage management but would also result in losing its significance for tourism. The meanings of the heritage would be reconstructed and reshaped by drawing on the changes in the society in which we live. Shackel (2005, p.25) argues that 'preserving heritage is more than just freezing a moment in time. Heritage is an expression of what people think is important'. Colonial heritage attractions would become a new heritage that constructs and enhances a new national identity, community identity and personal identity in present society. This is, of course, not devoid of important political and ethical issues, but this research reveals the existence of this issue and suggests that it should be subject to transparency and public deliberation, so that the post-colonial society can collectively discuss and decide how and what it wants the past to mean. There is a need for more awareness of the present multiple meanings and value of the heritage so that historic resources can be better managed for tourism.

\section{References}

Anico, M. (2009). Representing identities at local municipal museums: Cultural forums or identity bunkers? In M. Anico \& E. Peralta (Eds.), Heritage and Identity: Engagement and Demission in the Contemporary World (pp.63-75). London: Routledge.

Ashworth, G. J. (1998). Heritage, identity and interpreting a European sense of place. In D. Uzzell, \& R. Ballantyne (Eds.), Contemporary issues in heritage and environmental interpretation: problems and prospects (pp.112-132). London: Stationery Office. 
Ashworth, G. J. (2002). Holocaust tourism: the experience of Kraków-Kazimierz. International Research in Geographical and Environmental Education, 11(4), 363-367.

Assmann, A. (2011). Memory, Individual and Collective. In R. E. Goodin \& C. Tilly (Eds.), The Oxford handbook of contextual political analysis (pp. 210-224). Oxford: Oxford University Press.

Barnett, J. (2004). The Multiple Sorting Procedure. In G. Breakwell (Ed.), Doing social psychology research (pp. 289-304). Oxford: Blackwell Publisher, Ltd.

Biran, A., Poria, Y., \& Oren, G. (2011). Sought experiences at (dark) heritage sites. Annals of Tourism Research, 38(3), 820-841.

Bhandari, K. (2001). Recreating heritage in the southwest of Scotland. Current Issues in Tourism, 14(7), 669-683.

Byrne, D. (2003). Nervous Landscapes Race and Space in Australia. Journal of Social Archaeology, 3(2), 169-193.

Canter, D. (2004). A Partial Order Scalogram Analysis of Criminal Network Structures. Behaviormetrika, 31(2), 131-152.

Canter, D. V., Brown, J., \& Groat, L. (1985). A Multiple Sorting Procedure for studying conceptual systems. In M. Brenner, J. Brown \& D. Canter (eds.), The Research Interview: Uses and Approaches (pp. 79-114). London: Academic Press.

Chadha, A. (2006). Ambivalent Heritage Between Affect and Ideology in a Colonial Cemetery. Journal of Material Culture, 11(3), 339-363.

Chang, T. C., \& Teo, P. (2009). The Shophouse Hotel: Vernacular Heritage in a Creative City. Urban Studies, 46(2), 341-367

Cheer, J., \& Reeves, K. (2015). Colonial heritage and tourism: ethnic landscape perspectives. Journal of Heritage Tourism, 10(2), 151-166.

Chung, Y. S. S. (2003). Object as Exhibit: legitimising the building of the National Museum of Korea. International Journal of Heritage Studies, 9(3), 229-242.

Coxon, A. P. M. (1982). The User's Guide to Multidimensional Scaling. London: Heinemann Educational Books.

Crouch, D., \& Parker, G. (2003). 'Digging-up' Utopia? Space, practice and land use heritage. Geoforum, 34(3), 395-408.

Dolff-Bonekämper, G. (2008). Sites of memory and sites of discord: historical monuments as a medium for discussing conflict in Europe. In G. Fairclough, R. 
Harrison, J. H. Jameson, \& J. Schofield (Eds.), The Heritage Reader (pp.132138). London: Routledge.

Dolff-Bonekämper, G. (2010). Cultural Heritage and Conflict: the view from Europe. Museum International, 62(1-2), 14-19.

Garden, M. E. (2006). The Heritagescape: Looking at landscapes of the past. International Journal of Heritage Studies, 12(5), 394-411.

Graham, B. (2002). Heritage as knowledge: capital or culture? Urban studies, 39(5-6), $1003-1017$.

Groat, L. (1982). Meaning in post-modern architecture: An examination using the Multiple Sorting Task. Journal of Environmental Psychology, 2(1), 3-22.

Guttman, R., \& Greenbaum, C. W. (1998). Facet theory: Its Development and Current Status. European psychologist, 3(1), 13-36.

Harrison, R., Fairclough, G., Jameson, J. H., \& Schofield, J. (2008). Heritage, memory and modernity: An introduction. In G. Fairclough, R. Harrison, J. H. Jameson, \& J. Schofield (Eds.), The Heritage Reader. (pp.1-12). London: Routledge.

Harvey, D. C. (2001). Heritage Pasts and Heritage Presents: temporality, meaning and the scope of heritage studies. International Journal of Heritage Studies, 7(4), 319-338.

Henderson, J. C. (2001). Conserving colonial heritage: Raffles Hotel in Singapore. International Journal of Heritage Studies, 7(1), 7-24.

Hubbard, P. (1994). Professional vs Lay tastes in design control—an empirical investigation. Planning Practice and Research, 9(3), 271-287.

Hubbard, P. (1996a). Conflicting interpretations of architecture: an empirical investigation. Journal of Environmental Psychology, 16(2), 75-92.

Hubbard, P. (1996b). Urban design and city representation: social representations of entrepreneurial landscapes. Urban Studies, 33(8), 1441-1461.

Jennings, E. T. (2003). From Indochine to Indochic: The Lang Bian/Dalat Palace Hotel and French Colonial Leisure, Power and Culture. Modern Asian Studies, 37(1), 159-194.

Jin, J. H. (2008). Demolishing Colony: The Demolition of the Old Government-General Building of Choson. In T. Tangherlini \& S. Yea (Eds.), Sitings: Critical Approaches to Korean Geography (39-58). Hawai'i: University of Hawai'i Press. 
Kaplan, F. E. S. (2009). The ancient city walls of Great Benin: Colonialism, urban heritage and cultural identity in contemporary Nigeria. In M. Anico \& E. Peralta (Eds.), Heritage and Identity: Engagement and Demission in the Contemporary World (pp.156-168). London: Routledge.

Kim, S. (2009). Re-locating the National: spatialization of the national past in Seoul. Policy Futures in Education, 7(2), 256-265.

Langley, L. (2011). How may heritage be used to defuse religious or ethnic tensions in the Mediterranean region and should it be used in this way?. Rosetta, 9, 1-15.

Logan, W., \& Reeves, K. (2009). Introduction: Remembering places of pain and shame. In W. Logan \& K. Reeves (Eds.), Places of pain and shame: dealing with 'difficult heritage', (pp.1-14). London: Routledge.

Lowenthal, D. (1998). The heritage crusade and the spoils of history. Cambridge University Press.

Macdonald, S. (2006 a). Undesirable heritage: Fascist material culture and historical consciousness in Nuremberg. International Journal of Heritage Studies, 12(1), 9-28.

Macdonald, S. (2006 b). Words in Stone? Agency and Identity in a Nazi Landscape. Journal of Material Culture, 11(1/2), 105-126.

Massara, F., \& Severino, F. (2013). Psychological distance in the heritage experience. Annals of Tourism Research, 42, 108-129.

Meskell, L. (2002). Negative Heritage and Past Mastering in Archaeology. Anthropological Quarterly, 75(3), 557-574.

Moles, K. (2009). A landscape of memories: Layers of meaning in a Dublin park. In M. Anico \& E. Peralta (Eds.), Heritage and Identity: Engagement and Demission in the Contemporary World (pp.129-140). London: Routledge.

Palmer, C. (1994). TOURISM AND COLONIALISM: The Experience of the Bahamas. Annals of Tourism Research, 21(4), 792-811.

Palmer, C. (1999). Tourism and the symbols of identity. Tourism Management, 20(3), 313-321.

Palmer, C. (2005). AN ETHNOGRAPHY OF ENGLISHNESS: Experiencing Identity through Tourism. Annals of Tourism Research, 32(1), 7-27.

Park, S. (2012). Speaking with the Colonial Ghosts and Pungsu Rumour in Contemporary South Korea (1990-2006): The Pungsu (Feng Shui) Invasion 
Story Surrounding the Demolition of the Former Japanese Colonial-General Building and Iron Spikes. Journal for Cultural Research, 16(1), 21-42.

Peleggi, M. (2005). Consuming colonial nostalgia: The monumentalisation of historic hotels in urban South-East Asia. Asia Pacific Viewpoint, 46(3), 255-265.

Prats, L. (2009). Heritage according to scale. In M. Anico \& E. Peralta (Eds.), Heritage and Identity: Engagement and Demission in the Contemporary World (pp.7689). London: Routledge.

Rakić, T. (2008). World Heritage, Tourism and National Identity: a case study of the Acropolis in Athens, Greece. Unpublished Doctoral Degree thesis. Napier University, UK.

Ravi, S. (2008). Modernity, Imperialism and the Pleasures of Travel: The Continental Hotel in Saigon. Asian Studies Review, 32(4), 475-490.

Rico, T. (2008). Negative Heritage: The Place of Conflict in World Heritage. Conservation and Management of Archaeological Site, 10(4), 344-352.

Scott, M., \& Canter, D. V. (1997). Picture or place? A multiple sorting study of landscape. Journal of Environmental Psychology, 17(4), 263-281.

Shaw, B. J., \& Jones, R. (1997). Contested urban heritage: Voices from the periphery. Aldershot: Ashgate Publishing Limited.

Shackel, P. A. (2005). Local identity, national memory, and heritage tourism: creating a sense of place with archaeology. Illinois Antiquity, 40(3), 24-26.

Sixsmith, J. (1986). The meaning of home: An exploratory study of environmental experience. Journal of Environmental Psychology, 6(4), 281-298.

Smith, L. (2006). Uses of Heritage. London: Routledge.

Smith, L. (2007). General Introduction. In L. Smith (Ed.), Cultural Heritage: Critical concepts in Media and Cultural Studies (pp.1-21). London: Routledge.

Taylor, P. J. (2002). A partial order scalogram analysis of communication behavior in crisis negotiation with the prediction of outcome. International Journal of Conflict Management, 13(1), 4-37.

Tunbridge, J., \& Ashworth, G. J. (1996). Dissonant heritage: the management of the past as a resource in conflict. London: John Wiley \& Sons.

Tunbridge, J., Jones, R., \& Shaw, B. J. (1996). Editorial: Contested heritage: Perth, 1995. International Journal of Heritage Studies, 2(1-2), 5-9. 
Tzfati, E., Sein, M., Rubinov, A., Raveh, A., \& Bick, A. (2011). Pretreatment of wastewater: optimal coagulant selection using Partial Order Scaling Analysis (POSA). Journal of hazardous materials, 190(1), 51-59.

UNESCO. (2013). About World Heritage. Retrieved from http://whc.unesco.org/en/about/

Urry, J. (2000). Sociology beyond societies : mobilities for the twenty-first century. London: Routledge.

Uzzell, D. L. (1989). The hot interpretation of war and conflict. In D. Uzzell (Ed.), Heritage Interpretation: The National and Built Environment (Volume 1, pp.3347), London: Belhaven.

Uzzell, D. L. (1998). Interpreting our heritage: A theoretical interpretation. In D. Uzzell and R. Ballantyne (Eds), Contemporary Issues in Heritage and Environmental Interpretation: Problems and Prospects (pp. 11-25). London: The stationery Office.

Uzzell, D. L. (2009, April 23-26). When and where memory and history meet. Invited paper to the $19^{\text {th }}$ International Convention on Culture and Peace 'Life stories, symbolic sites and reconstruction of identities in peace building', Gernika, Spain.

Uzzell, D. (2015). Postscript 1: The Time of Place. In M. L. S. Sørensen \& D. V. Rose (Eds.), War and Cultural Heritage (pp. 251-260). New York: Cambridge University Press.

Uzzell, D., \& Ballantyne, R. (1998). Heritage that hurts: interpretation in a postmodern world. In D. Uzzell \& R. Ballantyne (Eds.), Contemporary issues in heritage and environmental interpretation: Problems and prospects (pp. 152-171). London: The Stationery Office.

Wilson, M. (1995). Structuring Qualitative data: Multidimensional Scalogram Analysis. In G. M. Breakwell, S. Hammond \& C. Fife-Schaw (Eds.), Research Methods in Psychology (pp.259-273). London: SAGE Publication, Ltd.

Wilson, M. (1996). The socialization of architectural preference. Journal of Environmental Psychology, 16(1), 33-44.

Wilson, M., \& Canter, D. V. (1990). The Development of Central Concepts during Professional Education: An example of a Multivariate Model of the Concept of 
Architectural Style. Applied Psychology: An international Review, 39(4), 431455.

Wilson, M., \& Hammond, S. (2000). Structured Qualitative Data Using a Scaling Procedure. In G. M. Breakwell, S. Hammond \& C. Fife-Schaw (Eds.), Research Methods in Psychology (pp.281-293). London: SAGE publications, Ltd.

Wilson, M., \& Mackenzie, N. E. (2000). Social attributions based on domestic interiors. Journal of Environmental Psychology, 20(4), 343-354.

Witcomb, A. (2009). The past in the present: Towards a politics of care at the National Trust of Australia (WA). In M. Anico \& E. Peralta (Eds.), Heritage and Identity: Engagement and Demission in the Contemporary World (pp.169-180). London: Routledge.

Wong, C. (2013). The sankzation of colonial history: authencity, heritage interpretation and the case of Macau's tour guides. Journal of Sustainable Tourism, 20(6), 915-931. 